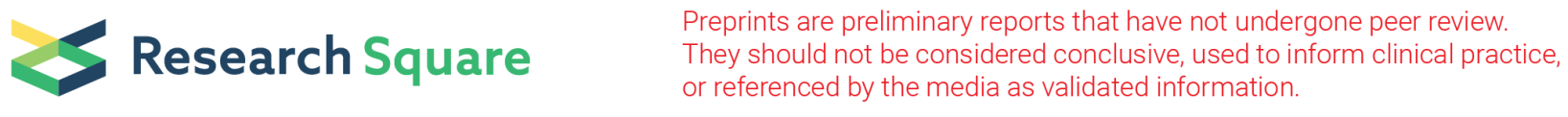

\title{
Growth and nitrogen accumulation assessment of banana (Musa acuminata) after exposure to hydroquinone in a charcoal-ultisol mix
}

Beckley Ikhajiagbe ( $\sim$ beckley.ikhajiagbe@uniben.edu )

University of Benin, Nlgeria https://orcid.org/0000-0003-2834-7447

Marychoice N. Ebinum

University of Benin, Nlgeria

\section{Research Article}

Keywords: charcoal-ultisol mix, nitrogen accumulation

Posted Date: November 23rd, 2021

DOI: https://doi.org/10.21203/rs.3.rs-1104888/v1

License: @ (i) This work is licensed under a Creative Commons Attribution 4.0 International License. Read Full License 


\section{Abstract}

The present study investigates plant growth and nitrogen accumulation assessment of young banana plant (Musa acuminata) after exposure to hydroquinone (a mutagen) in a charcoal-ultisol mix. Charcoal was obtained from the wood of Pentaclethra macrophylla aerobically, and was crushed into a smooth powdered form. This was mixed with an ultisol obtained from the University of Benin Botanic garden. Different levels of the soil-charcoal mix were prepared as follows; $100 \%$ charcoal, $75 \%$ charcoal- $25 \%$ soil, $50 \%$ charcoal- $50 \%$ soil, $25 \%$ charcoal- $75 \%$ soil, and $100 \%$ sand. The charcoal-ultisol mix was then amended with $5 \mathrm{ppm}$ hydroquinone one week before propagating young banana suckers. Results showed that sprouting began fifteen days after propagation. There were also different changes in plant height in the various soil treatments; the lowest was reported in the $75-25 \mathrm{charcoal}$ ultisol mix (10.50 cm), compared to $45.83 \mathrm{~cm}$ in plants sown in $100 \%$ charcoals. Foliar yield was lowest in the $75-25$ charcoal-ultisol mix ( 8.55 grams per plant), compared to 29.15 grams per plant in the $100 \%$ charcoal. The below ground morphological characteristics test plant revealed that there were significant differences between the growth parameters. Nitrate nitrogen, Ammonia Nitrogen and total nitrogen were significantly accumulated on the leaves of plant. However, higher nitrogen accumulation in the leaves was found in treatment with high charcoal percentage.

\section{Introduction}

So many soils in Nigeria today are less productive because of reasons like over-cropping, erosion, leaching and acidification of the soil, hence the need for ways to improve the soil and also improve crop productivity. The amount of nitrogen taken up by the crop has a major impact on overall crop growth rate (Shardana and Sheoran, 2011). The rate of nitrogen uptake of crops is highly variable during crop development and between years and sites. However, under ample soil nitrogen availability, crop nitrogen accumulation is highly related to crop growth rate and to biomass accumulation. Hydroquinoneis mutagenic in vitro and in vivo, having caused genotoxicity or chromosomal aberrations in rodent bone-marrow cells (McGregor, 2007). Although it has been known to play essential role as an oxidizing and reducing agent, and it is frequently used in cosmetic industries for skin whitening, its role in agriculture as a seed germination enhancer is rarely known. The use of mutation in plant is helpful for the improvement of one or two traits. Mutation can be induced either by chemical or physical agents. The use of mutagens in plant has generated striking results. According to Ahloowalia and Maluszxynski (2001), thousands of cultivars have been generated through induced mutants. Although various mutagenic agents have been known to improve growth and survival of plant but at high concentration it causes negative mutation and retard growth (Akhatar et. al., 2012; Ballare, 1996). Although most studies indicate no direct mutagenicity, many have shown that hydroquinone causes chromosomal aberrations, abnormal mitosis, formation of micronuclei, aneuploidy, and sister chromatid exchange (Decaprio, 1999). It has been reported that the application of hydroquinone not only increased seed germination, stomatal resistance and lowered the rate transpiration but also inhibits the growth of seed-borne fungi and reduced the growth of soybean seedlings (Barosky et al., 1999; Elwakil, 2003). Keller et al., 2008 revealed that hydroquinone is suppressive to plants but at the same time, it ameliorates growth and germination of seeds. Hydroquinone was observed to increase seed germination and growth on lower concentrations; however, at concentrations higher than 20 ppm, it is inhibitory to the seed germination and growth Kamran, et al. (2017). Charcoal is a lightweight black carbon and ash residue produced by removing water and other volatile constituents from animal and vegetation substances. Charcoal is used to improve soil quality, it raises the soil temperature, conserve the soil moisture, absorb harmful metals and improve vitality of the microbes in the soil (Glaser,et. al., 2001). Many scientists recommend the use of charcoal to achieve better plant growth (Steiner et. al., 2002). Ultisols are mineral soils which contain no calcareous material anywhere within the soil, have less than 10 weather able minerals in extreme top layer of soils and have less than $35 \%$ base saturation throughout the soil. Ultisol are quite acidic having a pH less than 5 . Acid soil, particularly in the subsurface restricts root access to water. Kloss et al. (2012) reported that charcoal are known to basify acidic soils in addition to improving nutrient retention and exchange and delivering a pulse of water soluble elements available for plants' soil fauna (Wardle, et. al., 1998 and DeLuca et. al., 2012) and improving soil water holding capacity (Bruun et. al., 2014). Charcoal has been known for years for improving soil fertility and also as a sorbing agent taking up chemicals that could have been harmful to the plant system. Steiner et al. (2007) found out in his experiment that after the second harvest, significantly more fertilizer nitrogen remained in the soil amended with charcoal (15.6\% of applied nitrogen) than on plots without organic amendment (9.7\%). The results of the nitrogen experiments by Burger and Jackson (2003) suggested a very dynamic role of microbially bound nitrogen and highlight the importance of nitrogen immobilization that is taking place simultaneously with inorganic-nitrogen production by mineralization. They concluded that greater carbon availability stimulates microbial activity resulting in greater nitrogen demand, promoting immobilization and recycling of nitrate.The basis of this study was to identify the mutagenic effect of nitrogen accumulation of the banana plant after exposure to hydroquinone in a charcoal-ultisol mix.

\section{Materials And Methods}

\section{Site Preparation}

A portion of land was assigned in the botanical garden of University of Benin Ugbowo Campus. It was cleared, packed and burnt. A green house of 13.7 by 3.05 meters was constructed using woods and roofed with plastic roofing (transparent) to enable sunlight penetration. Thirty polythene bags were used for the planting of the suckers in the charcoal-ultisol mix. The polythene bag has sizes of 0.48 by 0.38 meters.

\section{Preparation of Chemical application}

0.5 grammes of hydroquinone was weighed and mixed with 10 liters of water for application. 5 parts per million was used. It was applied to the charcoalultisol mix one week before planting the suckers and thirty times after planting under the guidance of my supervisor.

The wood of Pentaclethra macrophylla (oil bean tree) was obtained from Egor and burned into charcoal at Egor village in Edo state. It was grinded to powder form. $2.4 \mathrm{~kg}$ of charcoal only in first treatment, $1.8 \mathrm{~kg}$ of charcoal and $2 \mathrm{~kg}$ of sand in the second treatment, $1.2 \mathrm{~kg}$ of charcoal and $4 \mathrm{~kg}$ of sand in the third treatment, $0.6 \mathrm{~kg}$ of charcoal and $6 \mathrm{~kg}$ of sand into the fourth treatment and $8 \mathrm{~kg}$ of sand only in the fifth treatment. The charcoal and sand were properly mixed together. 


\section{Treatment preparation and Designation:}

There were a total of five treatments and six replicates; each of this was prepared in similar way except that the quantity of charcoal and sand was different in each treatment. The charcoal was obtained by burning the wood of Pentaclethra macrophylla Benth. (oil bean tree) in an enclosed system, then grinding it to a smooth powdered form. The ultisol as classified by Ogeh and Ogwurike, (2006) their project titled influence of Agricultural land use type on some soil properties in Midwestern Nigeria was collected at the botanical garden located at department of plant biology and biotechnology, University of Benin.

\section{Planting}

The banana was planted from suckers. The suckers had fresh weight that ranges from 0.2 to $2.0 \mathrm{~kg}$. The pseudostems (false root covering) were peeled out from the suckers before planting, to enable the growth of lateral meristems.

\section{Husbandary}

during the cause of the experiment there was constant wetting and weeding of grasses. The method of United States Department of Agriculture (USDA, 1998) guided the application of moisture to the soil to ensure the soil was neither water logged nor the plant water starved.

\section{Determination of growth parameters}

Plant growth was determined by the following above ground and below ground morphological characteristics;

i. Number of Leaves, number of shoot sprout per corm, number of fibrous roots and number of primary branches: This was carried out by counting their numbers on the plants of each of the treatment.

ii Change in plant height and average length of root: These were determined using a ruler calibrated in centimeters. The ruler was placed vertically from the soil surface to the terminal bud of the plant and the measurement recorded. Root lengths were measured using a ruler calibrated in centimeters at the end of the study. The root length was determined by using a thread to trace the length of the root from the base of the stem to the tip of the root. Thereafter, the length of the thread was determined and recorded using meter rule.

iii Plant width, leaf width, leaf length and leaf breadth: this was carried out by measuring them with a meter rule calibrated at centimeter.

iv Foliar yield: the leaves of the banana plant were harvested after 60 days of planting and oven dried at $800 \mathrm{C}$ for 72 hours. The weights were then taken and recorded.

v Shoot-root ratio: the shoot of the banana plant were harvested and oven dried at $800^{\circ} \mathrm{C}$ for 72 hours, then weighed using a weighing balance and recorded. The banana root was harvested, washed, oven dried at $800^{\circ} \mathrm{C}$ for 72 hours, then weighed also. The root weight was subtracted from plant weight to get the shoot-root ratio.

vi Dry weight of the root and dry weight of the plant: the fresh plant samples were gathered and oven dried at $800^{\circ} \mathrm{C}$ for 72 hours and then weighed on a weighing balance. The weighing was carried out at 2 hours interval until a constant weight was obtained.

vii Number of necrotic and chlorotic leaves were counted in each plant and recorded.

Chemical analysis

\section{Determination of total nitrogen}

The plant samples were air dried, pulverized to fine powder, and stored in clean dried sample bottles. Thereafter, the samples were digested by weighing $0.2 \mathrm{~g}$ of a finely ground plant sample into $30 \mathrm{ml} \mathrm{Kjedahl} \mathrm{flask.} \mathrm{One} \mathrm{tablet} \mathrm{of} \mathrm{Kjedahl} \mathrm{catalyst} \mathrm{and} 4.0 \mathrm{ml}$ of concentrated sulfuric acid ( $\mathrm{H} 2 \mathrm{SO} 4)$ were added, the flask were carefully and properly shaken to ensure complete mixing. The flask was then placed on a Kjedahl heater and digested for $45 \mathrm{mins}$. Upon digestion, the mixture was clear and the flask was removed from the heater and allowed to cool. 10ml of distilled water was added and filtered with Whatman filter paper into a $100 \mathrm{ml}$ flask and made up with distilled water, to $100 \mathrm{ml}$ mark. The flask was properly labeled. The Colorimetric determination of total nitrogen was done by measuring $5 \mathrm{ml}$ of the filtrate from the digest and was transferred with the aid of a $10 \mathrm{ml}$ pipette into a $25 \mathrm{ml}$ standard flask. $2.5 \mathrm{ml}$ of the Alkaline Phenate was added and the solution shaken to mix properly. Then $1 \mathrm{ml}$ of Sodium Potassium Tartarate was added, shaken properly followed by the addition $2.5 \mathrm{ml}$ of sodium hypochlorite. There after the solution was made up to the $25 \mathrm{ml}$ mark with distilled water and the absorbance of the resultant solution measured with the aid of UV/visible spectrophotometer, at $630 \mathrm{~nm}$. The Nitrogen standards were treated the same way with the sample.

\section{Determination of ammonium nitrogen}

The extraction of ammonium from plant sample was done by weighing $10 \mathrm{~g}$ of the finely pulverized plant sample into a clean dried $250 \mathrm{ml}$ plastic bottle. Then $40 \mathrm{ml}$ of the extracting solution was added and the mixture shaken on orbital shaker for 30 minutes after which it was carefully filter with the aid of a filter paper. The filtrate was stored in a clean, dry sample bottle to be used for ammonium nitrogen and nitrate nitrogen determination. The Colorimetric determination of ammonium nitrogen was also done by measuring $5 \mathrm{ml}$ of the filtrate which was immediately transferred with the aid of a $10 \mathrm{ml}$ pipette into a $25 \mathrm{ml}$ standard flask. $2.5 \mathrm{ml}$ of the Alkaline Phenate was added and the solution shaken to mix properly. Then $1 \mathrm{ml}$ of Sodium Potassium Tartarate was added, shaken properly followed by the addition $2.5 \mathrm{ml}$ of sodium hypochlorite. There after the solution was made up to the $25 \mathrm{ml}$ mark with distilled water and the 
absorbance of the resultant solution measured with the aid of UV/visible spectrophotometer, at $636 \mathrm{~nm}$. The Ammonium standards were treated the same way with the sample.

\section{Determination of nitrate nitrogen}

For the Determination of nitrate nitrogen, $10 \mathrm{ml}$ of the filtrate (from extraction of ammonium nitrogen) was transferred into a $50 \mathrm{ml}$ flask. Then $2 \mathrm{ml}$ of brucine was added and rapidly followed with addition of $10 \mathrm{ml}$ concentrated $\mathrm{H} 2 \mathrm{SO} 4$. This solution was properly mixed and allowed to stand for $10 \mathrm{mins}$, after which it was made up to $50 \mathrm{ml}$ mark with distilled water.The standard solutions were also treated same way. The absorbance of the sample solution and standard solutions were measured with the aid of the UV/Visible Spectrophotometer, at 470nm.

\section{Statistical Analysis}

All data obtained in the research were subjected to one way analysis of variance using SPSS statistical package version 16 . The means were separated using Duncan multiple range test. Necessary selected parameters were also accessed to the extent that a Pearson's correlation was conducted to establish possible significant relationship amongst any two parameters. The principal component analysis was also conducted where necessary to ascertain the possibility for stand out parameters towards the determination of the experimental goals. Hierarchical cluster was also performed wherein dendogram was presented to show possible link or possible clustering amongst treatment for future genetic assessment. Box and whisker's plot were also presented for selected parameters to show percentiles and ranges, using media as a means of central tendency.

\section{Results And Discussion}

\section{Morphological characteristics}

the results of the study relating to the above and below ground morphological characteristics have been represented on table one and table two respectively. there were an average of 2.33 shoot sprouts per comb in the plants sown in ch100 sn0, this did not significantly differ from the value obtained in Ch25 sn75 (5.67) $(P>0.05)$ the implication been that the composition of charcoal to soil did not affect the number of sprouted shoots per corm or rhizome. Change in plant height was reportedly lowest in the $75-25$.

Table 1

Selected above-ground morphological characteristics of the test plant at 60 days after sowing

\begin{tabular}{|c|c|c|c|c|c|c|c|c|c|c|}
\hline & $\begin{array}{l}\text { No. of shoot sprouts } \\
\text { per corm/rhizome }\end{array}$ & $\begin{array}{l}\text { Plant } \\
\text { height } \\
\text { (cm) }\end{array}$ & $\begin{array}{l}\text { Plant } \\
\text { width } \\
\text { (cm) }\end{array}$ & $\begin{array}{l}\text { Leaf } \\
\text { Number }\end{array}$ & $\begin{array}{l}\text { Leaf } \\
\text { length } \\
\text { (cm) }\end{array}$ & $\begin{array}{l}\text { Leaf } \\
\text { breadth } \\
\text { (cm) }\end{array}$ & $\begin{array}{l}\text { Foliar } \\
\text { yield } \\
\text { (g/plant) }\end{array}$ & $\begin{array}{l}\text { Plant } \\
\text { dry wt. } \\
\text { (g) }\end{array}$ & $\begin{array}{l}\text { No of } \\
\text { chlorotic } \\
\text { leafs }\end{array}$ & $\begin{array}{l}\text { No of } \\
\text { necrotic } \\
\text { leafs }\end{array}$ \\
\hline Ch100\%,Sn0\% & $2.33^{a}$ & $45.83^{d}$ & $2.83^{a}$ & $14.33^{b}$ & $16.67^{d}$ & $7.33^{b}$ & $29.15^{d}$ & $71.65^{d}$ & $3.00^{a}$ & $3.33^{a}$ \\
\hline Ch75\%,Sn25\% & $3.00^{a}$ & $4.50^{a}$ & $2.27^{\mathrm{a}}$ & $2.33^{a}$ & $2.60^{a}$ & $3.17^{a}$ & $8.55^{a}$ & $14.48^{a}$ & $1.33^{a}$ & $2.33^{a}$ \\
\hline Ch50\%,Sn50\% & $4.00^{a}$ & $31.83^{c}$ & $2.83^{a}$ & $14.33^{b}$ & $11.53^{c}$ & $4.53^{a}$ & $23.54^{c}$ & $54.21_{c}$ & $2.33^{a}$ & $2.33^{a}$ \\
\hline Ch25\%,Sn75\% & $5.67^{a}$ & $23.83^{b}$ & $3.50^{a}$ & $10.67^{b}$ & $9.10^{\mathrm{b}}$ & $4.27^{a}$ & $16.03^{b}$ & $46.11^{b}$ & $3.33^{a}$ & $3.00^{a}$ \\
\hline Ch0\%,Sn100\% & $3.00^{a}$ & $34.83^{c}$ & $2.67^{a}$ & $14.00^{\mathrm{b}}$ & $12.17^{c}$ & $5.83^{a}$ & $20.51^{c}$ & $51.45^{\mathrm{b}}$ & $2.00^{a}$ & $3.00^{a}$ \\
\hline P-value & 0.293 & 0.00 & 0.717 & 0.010 & 0.00 & 0.035 & 0.00 & 0.00 & 0.316 & 0.785 \\
\hline Significance & $P>0.05$ & $P<0.01$ & $P>0.05$ & $P<0.05$ & $P<0.01$ & $P<0.05$ & $P<0.01$ & $P<0.01$ & $P>0.05$ & $P>0.05$ \\
\hline
\end{tabular}

charcoal-ultisol mix $(10.50 \mathrm{~cm})$ compared to the 100-0 charcoal ultisol-mix $(45.83 \mathrm{~cm})$ generally there were different changes in plant height in the various charcoal ultisol-mix levels. Only two leaves were present at sixty days after sowing in 75-25 charcoal ultisol-mix, however in the 100-0, 50-50, 25-75 and 0-100 charcoal-ultisol mix respectively there were a range of between 10 and 14 leaves per plant. Foliar yield again was lowest in the $75-25$ charcoal ultisol-mix ( 8.55 grams per plant) compared to 29.15 grams per plant in the $100-0$ charcoal ultisol-mix. The study show that there was no significant differences in the number of leaves that showed both chlorotic and necrotic signs $(P>0.05)$ (Table 1) 
Table 2

Selected below-ground morphological characteristics of the test plant at 60 days after sowing

\begin{tabular}{|llllll|}
\hline & Av. length of root & No. of primary roots & No. primary branches per root & Dry wt. of root & Shoot-root ratio \\
\hline Ch100\%,Sn0\% & $8.933^{\mathrm{b}}$ & $17.00^{\mathrm{b}}$ & $20.00^{\mathrm{c}}$ & $20.85^{\mathrm{c}}$ & $54.47^{\mathrm{d}}$ \\
\hline $\mathrm{Ch} 75 \%, \mathrm{Sn} 25 \%$ & $5.167^{\mathrm{a}}$ & $12.00^{\mathrm{a}}$ & $21.40^{\mathrm{c}}$ & $13.10^{\mathrm{a}}$ & $11.72^{\mathrm{a}}$ \\
\hline $\mathrm{Ch} 50 \%, \mathrm{Sn} 50 \%$ & $8.167^{\mathrm{b}}$ & $15.00^{\mathrm{a}}$ & $22.80^{\mathrm{c}}$ & $15.32^{\mathrm{a}} \& \mathrm{~b}$ & $40.22^{\mathrm{c}}$ \\
\hline Ch25\%,Sn75\% & $11.233^{\mathrm{c}}$ & $33.67^{\mathrm{d}}$ & $4.83^{\mathrm{a}}$ & $12.76^{\mathrm{a}}$ & $34.67^{\mathrm{b}}$ \\
\hline Ch0\%,Sn100\% & $8.833^{\mathrm{b}}$ & $27.00^{\mathrm{c}}$ & $13.97^{\mathrm{b}}$ & $17.30^{\mathrm{b}}$ & $33.15^{\mathrm{b}}$ \\
\hline P-value & 0.000 & 0.000 & 0.000 & 0.001 & 0.000 \\
\hline Significance & $\mathrm{P}<0.01$ & $\mathrm{P}<0.01$ & $\mathrm{P}<0.01$ & $\mathrm{P}<0.01$ & $\mathrm{P}<0.01$ \\
\hline
\end{tabular}

The selected below ground morphological characteristics of the test plant at sixty days after sowing, there were between twelve and thirty three primary (fibrous) roots in the test plant. The plants with the highest number of roots were the one sown in the 25-75 charcoal ultisol-mix. Dry weight of roots was highest in the 100-0 charcoal ultisol-mix (20.85 grams) compared to 13.10 grams in the $75-25$ charcoal ultisol-mix.Charcoal only had the highest values for change in plant height, leaf number, leaf length, leaf breadth, foliar yield and plant dry weight when compared to other treatments, meaning that treatment had a higher growth. This contradicts what Asai et al. (2009) and Gaskin et al., (2010) reports, which stated that decreased growth is regularly reported with charcoal amendments when not associated with fertilizer additions. Although, hydroquinone was introduced in this study, this may have been the reason for improved growth yield. Li et al. (2009) identified hydroquinone from Podophyllum hexandrum, as a growth enhancer for wheat seedling growth (Li et al., 2009). It was concluded by that hydroquinone increased the morphological growth parameters of plants at low concentration.

\section{Nitrogen accumulation}

At sixty days after planting nitrogen accumulation in the plant leaves was determined, result showed that there were significant changes in nitrate nitrogen accumulation in plants sown in the different level of charcoal ultisol-mix, the highest been obtained in the $75-25$ charcoal ultisol-mix $(9.76 \times 103$ ppm of nitrate nitrogen and $2.44 \times 103 \mathrm{ppm}$ of ammonia nitrogen) the question therefore arises why these plants with the highest nitrogen accumulation had low results when above ground morphological characteristics of the test plant at sixty days was accessed. As also presented in Table 3 total nitrogen ranged from $1.89-2.81 \%$ in all the treatments $(p<0.05)$.

Table 3

$\mathrm{N}$ accumulation into plant leaf

\begin{tabular}{|llll|}
\hline Samples & $\begin{array}{l}\text { Nitrate nitrogen } \\
\left(\times 10^{3} \mathbf{p p m}\right)\end{array}$ & Ammonia nitrogen $\left(\times 10^{3} \mathbf{p p m}\right)$ & $\begin{array}{l}\text { Total nitrogen } \\
(\%)\end{array}$ \\
\hline Ch100\%,Sn0\% & $4.90^{\mathrm{a}}$ & $1.71^{\mathrm{C}}$ & $2.8133^{\mathrm{b}}$ \\
\hline Ch75\%,Sn25\% & $9.76^{\mathrm{d}}$ & $2.44^{\mathrm{d}}$ & $1.8900^{\mathrm{a}}$ \\
\hline Ch50\%,Sn50\% & $6.35^{\mathrm{b}}$ & $1.16^{\mathrm{b}}$ & $2.6967^{\mathrm{b}}$ \\
\hline Ch25\%,Sn75\% & $5.93^{\mathrm{b}}$ & $0.89^{\mathrm{b}}$ & $2.6000^{\mathrm{b}}$ \\
\hline Ch0\%,Sn100\% & $8.90^{\mathrm{C}}$ & $0.46^{\mathrm{a}}$ & $1.8900^{\mathrm{a}}$ \\
\hline P-value & 0.00 & 0.00 & 0.11 \\
\hline Significance & $\mathrm{P}<0.01$ & $\mathrm{P}<0.01$ & $\mathrm{P}<0.05$ \\
\hline
\end{tabular}

High accumulations of free $\mathrm{NH} 4+$ in tissues are toxic because they dissipate pH gradients in the mitochondria and plastids (Epstein and Bloom, 2005). This might explain why the banana in that 75-25 charcoal ultisol mix had low growth rate. As also presented in Table 3 total nitrogen ranged from $1.89-2.81 \%$ in all the treatments $(p<0.05)$. Accumulation of nitrate in plants can be limit growth if the rate of its uptake exceeds the rate of its reduction to ammonium (Luo et al., 1993). As suggested by McCall and Willumsen (1998), high rates of nitrate application increase the plant nitrate content without increasing the yield. Investigations have indicated that a high nitrate accumulation in plants results in nitrite production, which is converted into nitric oxide (NO) which, together with 02-, could be rapidly catalyzed by nitrate reductase into peroxynitrite (ONOO-) which is highly toxic to plants (Durner and Klessig, 1999; Lamattina et al., 2003). Therefore, high nitrate accumulation in plants is harmful to human health (Ikemoto et al., 2002; Ishiwata et al., 2002) as well as to plant growth (Reddy and Menary, 1990). Also Weerasuriya and Yogaratnam (1989); Anderson et al. (2011) reported, that decrease in growth of Zea mays with increase in charcoal concentration may be attributed to the supra-optional concentration of nutrients in the plant. Lehmann (2007) also observed that crops respond positively to charcoal additions and may show growth reductions at very high applications, this could also be another reason while ch 75-25 charcoal ultisol mix had a low growth.

Percentage nitrate and ammonia nitrogen utilization by the plant was determined (Table 4) as presented, $58.96 \%$ of total nitrogen utilization by the plant was in the nitrate nitrogen form when the plant was sown in 75-25 charcoal ultisol-mix however, the lowest nitrate nitrogen utilization percent (17.77\%) was

Page 5/10 
obtained in the 100-0 charcoal ultisol-mix. similarly $15.1 \%$ of nitrogen utilization was attributed to ammonia nitrogen accumulation in the plants exposed to $75-25$ charcoal ultisol-mix as compared to $3.22 \%$ in the $0-100$ charcoal ultisol-mix $(P<0.01)$.

Table 4

Percentage Nitrate and ammonia-N utilization by plant

\begin{tabular}{|lll|}
\hline PLANT SAMPLE & Nitrate nitrogen(\%) & Ammonia nitrogen (\%) \\
\hline Ch100\%,Sn0\% & $17.7705^{\mathrm{a}}$ & $5.5678^{\mathrm{b}}$ \\
\hline Ch75\%,Sn25\% & $58.960^{\mathrm{e}}$ & $15.1990^{\mathrm{c}}$ \\
\hline Ch50\%,Sn50\% & $31.4339^{\mathrm{c}}$ & $6.0922^{\mathrm{b}}$ \\
\hline Ch25\%,Sn75\% & $25.6034^{\mathrm{b}}$ & $4.0766^{\mathrm{a}}$ \\
\hline Ch0\%,Sn100\% & $51.7984^{\mathrm{d}}$ & $3.2243^{\mathrm{a}}$ \\
\hline p-value & 0.000 & 0.000 \\
\hline Significance & $\mathrm{P}<0.01$ & $\mathrm{P}<0.01$ \\
\hline
\end{tabular}

the plants, in this presentation when the index was greater than unity, it therefore implied that nitrogen was significantly hyper acummulated in the leaves as presentedresult showed that efficiency index ranged from 8.6-24.8 an indication that accumulation was significant but at different rates. The highest rate of hyper accumulation was reported in the plant sown in the 50-50 charcoal ultisol-mix (index $=24.88$ )

\section{Correlation of selected plant growth and yield parameter}

An attempt was made to correlate selected plant growth and yield parameter of the test plant on exposure to hydroquinone in the charcoal ultisol-mix. Result showed that plant height significantly correlated with leaf number $(R=0.781, P<0.01)$ leave length $(R=0.98, P<0.01)$. These also included leaf number, leaf breadth, plant dry weight, average length of root, dry weight of shoot and dry weight of root. Result showed that foliar yields highly negatively correlated with total foliar nitrate nitrogen $(R=-0.79, P<0.01)$, the implication been that significant accumulation of nitrate nitrogen reduced foliar yield in the test plants on exposure to hydroquinone in the charcoal ultisol-mix. These negative correlationship also existed between plant dry weight and nitrate nitrogen as well as the incidence of chlorosis and nitrate nitrogen. The question therefore, what is the implication of hydroquinone in nitrogen metabolism in plants? Study shows that hydroquinone not only inhibits the seed borne fungi but also has an effect in improving the growth of the plants and raise the yield by up to $50 \%$ more comparing to the untreated treatments. (Mohamed, 2003) this phenomenon has also been shown by Chinese author (Boeckx et al., 2000) who indicated that hydroquinone functions as urease inhibitor and improve the urea nitrogen recovery by spring wheat with $34 \%$ as compared to the treatment where only urea was applied. Because hydroquinone in this study was at low concentration, it ended up improving the growth of the plant. The literature revealed that hydroquinone is suppressive to plants but at the same time, it ameliorates growth of plants.bla et al results also showed a similar pattern of increased lettuce seed growth at lower concentrations and inhibition on higher concentrations 
Table 5

Correlation of selected plant growth and yield parameter

\begin{tabular}{|c|c|c|c|c|c|c|c|c|c|c|c|c|c|}
\hline & $\begin{array}{l}\text { Plant } \\
\text { height }\end{array}$ & $\begin{array}{l}\text { Leaf } \\
\text { Number }\end{array}$ & $\begin{array}{l}\text { Leaf } \\
\text { length }\end{array}$ & $\begin{array}{l}\text { Leaf } \\
\text { breadth }\end{array}$ & $\begin{array}{l}\text { Foliar } \\
\text { yield }\end{array}$ & $\begin{array}{l}\text { Plant } \\
\text { dry wt. }\end{array}$ & $\begin{array}{l}\text { No of } \\
\text { chlorotic } \\
\text { leafs }\end{array}$ & $\begin{array}{l}\text { No of } \\
\text { necrotic } \\
\text { leafs }\end{array}$ & $\begin{array}{l}\text { Av } \\
\text { length } \\
\text { of root }\end{array}$ & $\begin{array}{l}\text { No of } \\
\text { primary } \\
\text { roots }\end{array}$ & $\begin{array}{l}\text { Dry } \\
\text { wt of } \\
\text { root }\end{array}$ & $\begin{array}{l}\text { Nitrate } \\
\mathbf{N}\end{array}$ & $\mathrm{N}_{\mathrm{N}}^{\text {Ammonia }}$ \\
\hline $\begin{array}{l}\text { Plant } \\
\text { height }\end{array}$ & 1 & & & & & & & & & & & & \\
\hline $\begin{array}{l}\text { Leaf } \\
\text { Number }\end{array}$ & $0.781^{\star \star}$ & 1 & & & & & & & & & & & \\
\hline $\begin{array}{l}\text { Leaf } \\
\text { length }\end{array}$ & $0.98^{\star *}$ & $0.725^{\star \star}$ & 1 & & & & & & & & & & \\
\hline $\begin{array}{l}\text { Leaf } \\
\text { breadth }\end{array}$ & $0.759 * \star$ & $0.578^{\star}$ & $0.715^{\star \star *}$ & 1 & & & & & & & & & \\
\hline Foliar yield & $0.961^{\star *}$ & $0.736^{\star \star}$ & $0.959 * *$ & $0.678^{\star *}$ & 1 & & & & & & & & \\
\hline $\begin{array}{l}\text { Plant dry } \\
\text { wt. }\end{array}$ & $0.976^{\star \star}$ & $0.776^{\star *}$ & $0.952^{\star \star}$ & $0.709 * *$ & $0.959 * *$ & 1 & & & & & & & \\
\hline $\begin{array}{l}\text { No of } \\
\text { chlorotic } \\
\text { leafs }\end{array}$ & 0.381 & 0.487 & 0.407 & 0.205 & 0.429 & 0.472 & 1 & & & & & & \\
\hline $\begin{array}{l}\text { No of } \\
\text { necrotic } \\
\text { leafs }\end{array}$ & 0.251 & 0.352 & 0.221 & 0.244 & 0.122 & 0.242 & 0.17 & 1 & & & & & \\
\hline $\begin{array}{l}\text { Av length } \\
\text { of root }\end{array}$ & $0.557^{\star}$ & 0.502 & $0.542^{\star}$ & 0.279 & 0.46 & $0.634^{*}$ & $0.584^{*}$ & 0.102 & 1 & & & & \\
\hline $\begin{array}{l}\text { No of } \\
\text { primary } \\
\text { roots }\end{array}$ & 0.173 & 0.235 & 0.147 & 0.033 & -0.02 & 0.205 & 0.292 & 0.168 & $0.811^{\star *}$ & 1 & & & \\
\hline $\begin{array}{l}\text { Dry wt of } \\
\text { root }\end{array}$ & $0.782^{\star \star}$ & 0.477 & $0.763^{* *}$ & $0.813^{\star \star}$ & $0.792^{\star *}$ & $0.73^{\star \star}$ & 0.178 & -0.06 & 0.154 & $-0.19 *$ & 1 & & \\
\hline Nitrate N & $-0.68 * \star$ & $-0.53^{\star *}$ & $-0.71^{\star}$ & -0.42 & $-0.73^{\star *}$ & $-0.79 * \star$ & $-0.600 *$ & -0.22 & -0.66 & -0.17 & -0.38 & 1 & \\
\hline $\begin{array}{l}\text { Ammonia } \\
\mathrm{N}\end{array}$ & -0.49 & -0.6 *夫 & -0.46 & -0.22 & -0.34 & -0.48 & -0.3 & -0.19 & $-0.69 \star \star$ & $-0.72^{\star \star}$ & -0.07 & 0.181 & 1 \\
\hline $\begin{array}{l}\text { Total } \\
\text { percentage } \\
\mathrm{N}\end{array}$ & 0.508 & 0.262 & $0.538^{*}$ & 0.209 & $0.612^{\star}$ & $0.588^{*}$ & 0.369 & -0.19 & $0.542^{\star}$ & 0.047 & 0.284 & $-0.80 * \star$ & -0.03 \\
\hline
\end{tabular}

**. Correlation is significant at the 0.01 level (2-tailed).

*. Correlation is significant at the 0.05 level (2-tailed). 
Table 6

Rotated Component Matrix

\begin{tabular}{|lll|}
\hline & \multicolumn{2}{l}{ RescaledComponent } \\
\hline & 1 & 2 \\
\hline Nitrate.N & -0.995 & -0.099 \\
\hline Total.perc.N & 0.810 & -0.040 \\
\hline Plant.dry.wt.. & 0.750 & 0.419 \\
\hline Foliar.yield.. & 0.708 & 0.285 \\
\hline Leaf.length. & 0.669 & 0.403 \\
\hline Plant.height & 0.644 & 0.434 \\
\hline No.of.chlorotic.leafs & 0.580 & 0.249 \\
\hline Leaf.breadth. & 0.402 & 0.188 \\
\hline Dry.wt..of.root & 0.383 & 0.034 \\
\hline Plant.width..cm & 0.279 & 0.134 \\
\hline No.of.necrotic.leafs & 0.205 & 0.175 \\
\hline Ammonia.N & -0.083 & -0.997 \\
\hline No..of.primary.roots & 0.104 & 0.717 \\
\hline Av..length.of.root & 0.596 & 0.639 \\
\hline Leaf.Number & 0.476 & 0.563 \\
\hline No..primary.branches.per.root & -0.095 & -0.504 \\
\hline No.of.shoot.sprouts.per.corm.rhizome & 0.137 & 0.282 \\
\hline aatation converged in 3 iterations. & & \\
\hline & & \\
\hline
\end{tabular}

Extraction Method: Principal Component Analysis.

Rotation Method: Varimax with Kaiser Normalization.

\section{The matrix is not positive definite.}

A principal component analysis was conducted to establish possible standout parameters in the realization of the research aims and objectives. As presented in table six in the rotated component matrixes of the selected parameters showed highly significant positive loadings of above 0.7 for nitrate nitrogen, total percentage nitrogen, plant dry weight and foliar nitrogen under rescaled component one but none in the rescaled component two, it is eventually suggested that rescaled component one could therefore be a possible factor that affected the outcome of the results. The implication of the results of the principal component analysis may just imply that nitrate nitrogen had a highly significant negative impact on the achievement of possible growth responses in the present studies which draw us back to the earlier question; does hydroquinone have a negative effect on nitrogen metabolism? On the basis of nitrogen accumulation, 75-25 charcoal ultisol mix had higher nitrogen accumulation but did badly in terms of above ground growth, although these study was only done within sixty days it is suggested therefore that perhaps if the plants was allowed to grow till maturity result might eventually differ (also see figure 2).Figure 3 shows the dendrogram for hierarchical cluster analysis of research data using the word method. It was observed that clusters were mostly formed within replicates but most importantly there was cluster formation between some replicates of the plant in 0-100 charcoal ultisol-mix and those in the 50-50 charcoal ultisol- mix.Figure 4 shows Box and Whisker plots for residual soil nitrogen at the end of the experiment, (sixty days after sowing) results showed that residual soil nitrogen in the $100-0$ charcaol-ultisol mix was an average of $0.32 \%$ whereas total soil nitrogen in $0-100$ charcoal ultisol-mix was an average of $0.19 \%$.

\section{Declarations}

\section{Conflict of Interests}

The authors declare no conflicts of interests

\section{References}

Barkosky, R.R., Butler, J. L., and Einhellig, F. A. (1999). Mechanisms of hydroquinone-induced growth reduction in leafy spurge. J. Chem. Ecol. 25,1611-1621.

Elwakil, A. (2003). Use of antioxidant hydroquinone in the control of seed-borne fungi of peanut with special reference to the production of good quality seed. Plant Pathol. 75-79. 
Keller, C. P., Barkosky, R. R., Seil, J. E., Mazurek, S. A. and Grundstad, M. L. (2008). The electrical response of Phaseolus vulgaris roots to abrupt exposure to hydroquinone. Plant Signal Behav. 3, 633-640.

Prasetyo, B. H., Suharta, N., Subagyo, H. and Hikmatullah (2001). Chemical and mineralogical properties of Sasambo Utisol. Indonesian Journal of Agricultural Science. 2 (2) 37-47.

Tyron, E. H. (1948). Effect of charcoal on certain physical, chemical, and biological properties of forest soils, Ecological Monographs, Ecological Society of America. 18(1): 407-429.

Ogawa, M. and Okimori, Y. (2010). Pioneering works in biochar research, Japan. Australian Journal of Soil Research. 48: 489-500.

Kolb, S. E., Fermanich, K. J. and Dornbush, M. E. (2009). Effects of charcoal quantity on microbial biomass and activity in temperate soils. Soil Science Society of America Journal. 73(4): 1178-1181.

Hutterer, K. L. (1983). The national and cultural history of Southeast Asian agriculture: ecological and evolutionary considerations. Antropos 78: $169-212$.

Laird, D. A., Fleming, P., Davis, D. D., Horton, R., Wang, B. and Karlen, D. L. (2010). Impact of biochar amendments on the quality of a typical Midwestern agricultural soil. Geoderma 158(3-4): 443-449.

Wood, T. S. and Baldwin, S. (1985). Fuelwood and charcoal use in developing countries. Annual Review of Energy. 10: 407-429.

McGregor, D. (2007). Hydroquinone: an evaluation of the human risks from its carcinogenic and mutagenic properties. Crit. Rev. Toxicol. 37(10): 887-914.

\section{Figures}

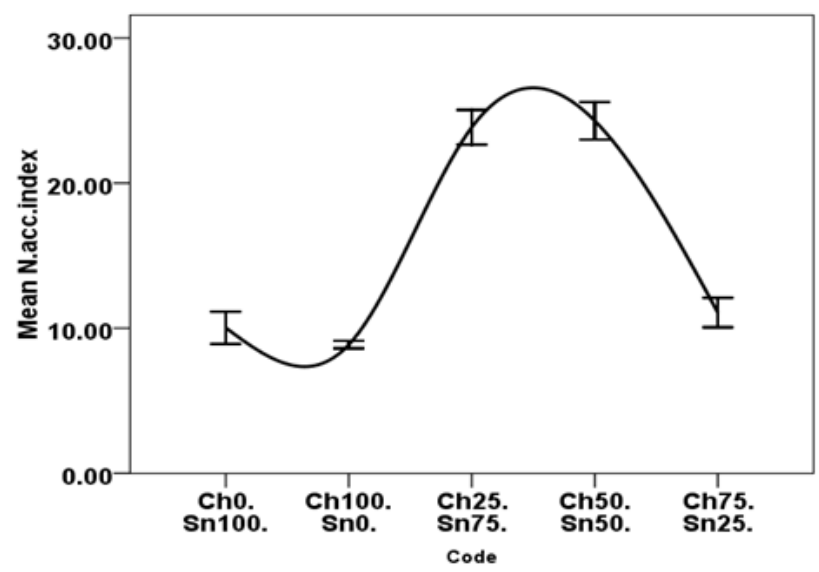

\section{Figure 1}

Efficiency index for $\mathrm{N}$-hyperaccumulation by plant. If index $>1$, then $\mathrm{N}$ was significantly hyperaccumulated.

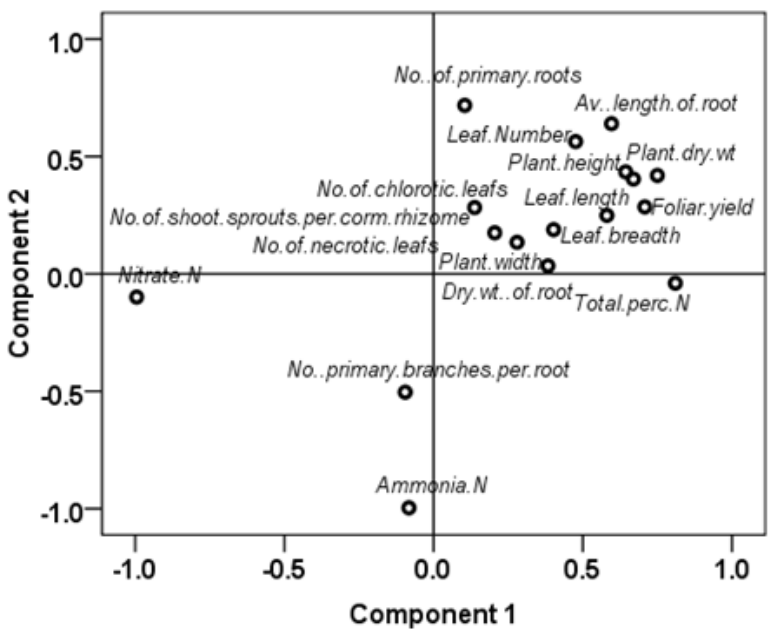

Figure 2

Component Plot in Rotated Space. The matrix is not positive definite 
Rescaled Distance Cluster Combine

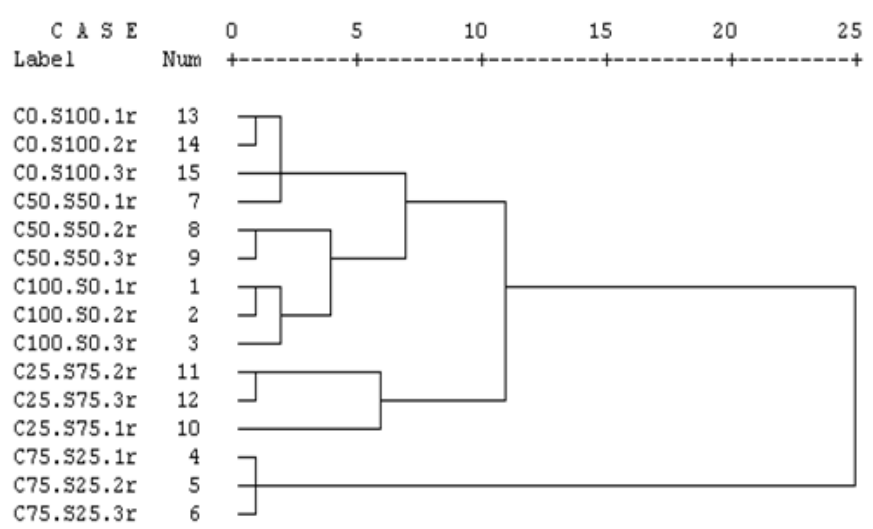

Figure 3

Dendrogram for hierarchical cluster analyses of research data using Ward method

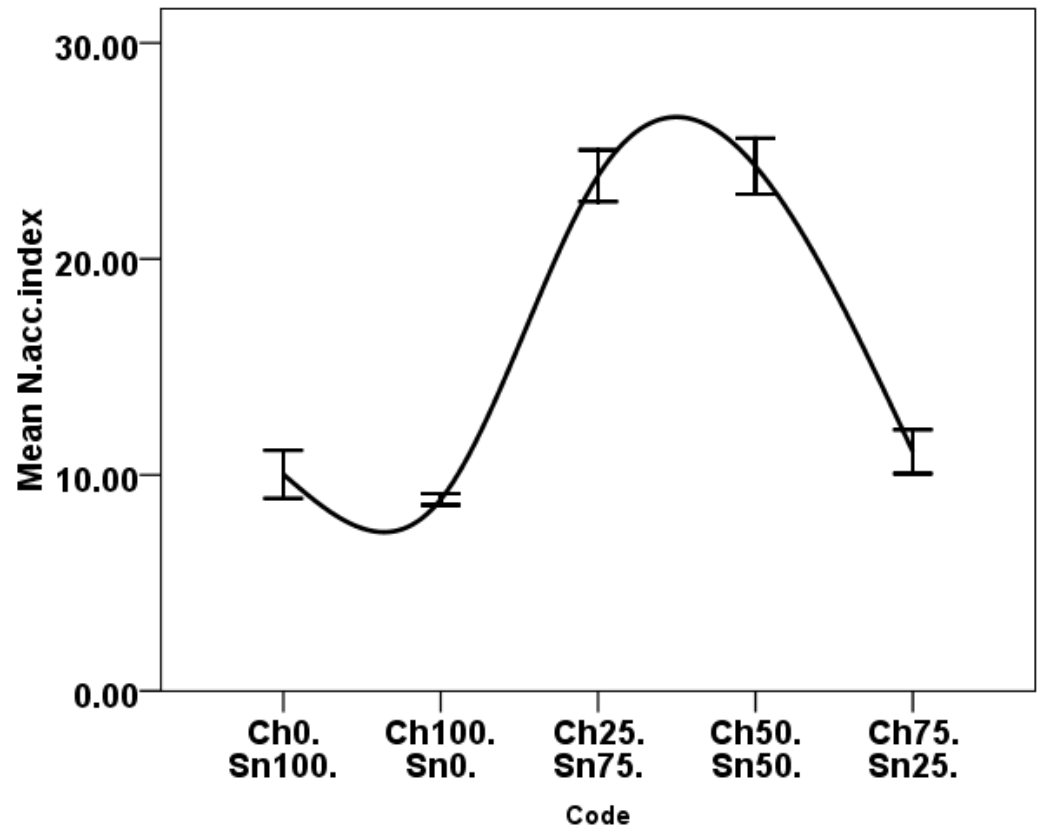

Figure 4

Efficiency index for $\mathrm{N}$-hyperaccumulation by plant

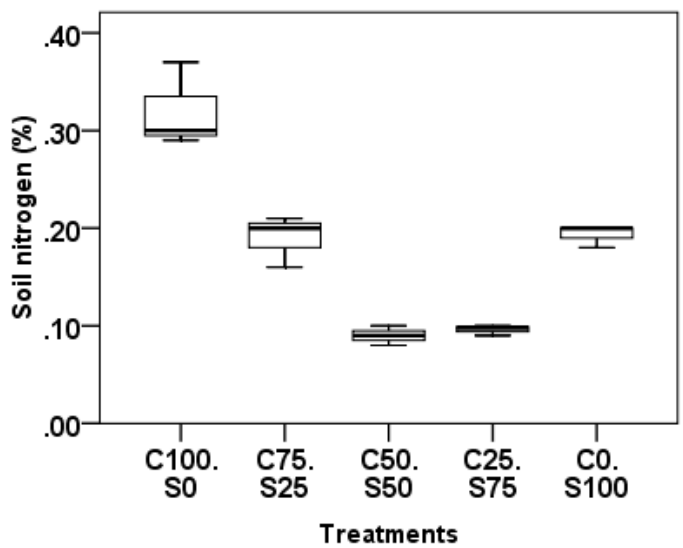

Figure 5

Box and Whisker plots for residual soil nitrogen at end of experiment 